\title{
THE ANALYSIS OF THE AARHUS CONVENTION IN THE CONTEXT OF GOOD ENVIRONMENTAL GOVERNANCE
}

\author{
Milan Počuča ${ }^{1}$, Marijana Mladenov ${ }^{2}$, Predrag Mirković ${ }^{3}$ \\ *Corresponding author E-mail: pocucabmilan@gmail.com
}

A R T I C L E I N F O
Review Article
Received: 07 September 2018
Accepted: 10 December 2018
doi:10.5937/ekoPolj1804615P
UDC 005.41:502/.504

Keywords:

Aarhus convention, public participation, public authorities, environmental protection

JEL: Q15, O13, Q58, K19, K49

\section{A B S T R A C T}

The purpose of this article is to examine mechanisms for public involvement in environmental governance from the perspective of the Aarhus Convention. Analysis method explained the connection between the basic postulates included in the Aarhus Convention and the main principles of good governance in environmental matters. Normative methods presented the provisions of the Aarhus Convention related to the right to an adequate environment and rights of access to information, public participation, and equal access to justice. By using the same method, the special attention was devoted to the transposition and implementation of the requirements of the Convention into the legal system of the Republic of Serbia. Through the case study research method, the authors examined the relevant practice of the Compliance Committee. Authors conclude that transposition of the requirements of the Aarhus Convention represents a valuable contribution in establishing good environmental governance.

(C) 2018 EA. All rights reserved.

\section{Introduction}

There is a growing acceptance that the concept of good governance includes the participatory democracy as its crucial component. Participation of the public in decision-making process has a significant impact on the improvement of quality of the resulting decisions and the credibility of this process (OHCHR -The Role of the Aarhus Convention in Promoting Good Governance and Human Rights).

Law and policy for ensuring the environmental protection, in most countries, basically rely on governments and public authorities. Crucial segments of governance mechanisms

1 Milan Počuča, PhD, Full professor, Faculty of Law for Commerce and Judiciary in Novi Sad, Geri Karolja Street no. 1, Novi Sad 21 000, Serbia, E-mail: pocucabmilan@gmail. com, https://orcid.org/0000-0002-5433-1134.

2 Marijana Mladenov, $\mathrm{PhD}$, Associate professor, Faculty of Law for Commerce and Judiciary in Novi Sad, Geri Karolja Street no. 1, Novi Sad 21 000, Serbia, E-mail: alavuk@pravnifakultet.info, https://orcid.org/0000-0002-4574-5159.

3 Predrag Mirković, PhD, Associate professor, Faculty of Law for Commerce and Judiciary in Novi Sad, Geri Karolja Street no. 1, Novi Sad 21 000, Serbia, E-mail: mirkovic@pravnifakultet.info, https://orcid.org/0000-0003-2323-040X. 
concerning the implementation of environmental legislation refer to transparency and public participation. The full engagement of public administration and civil society in the environmental policy making process is clearly perceived as the main purpose of the Aarhus Convention on Access to Information, Public Participation in Decision - Making and Access to Justice in Environmental Matters (Pallemaerts, 2011). The importance of the Aarhus Convention lies in its binding obligations on public authorities to ensure the right to an adequate environment through the three procedural rights, right to environmental information, right to participate in environmental decision-making and the right to access to justice in environmental matters.

The Aarhus Convention was negotiated within the framework of the UN Economic Commission for Europe (UNECE) and signed by 35 member states and by European Community at the ministerial conference "Environment for Europe" in Aarhus on 25 June 1998. This multilateral treaty entered into force on 30 October 2011, following ratification by 16 states. At this moment, the Aarhus Convention has 47 contracting parties, including the European Union.

Regarding the implementation of the rights provided by the Aarhus Convention, Article 3 establishes minimum standards, prescribing the obligation of states to take legislative, administrative and other measures in order to implement the provisions of the Convention. In addition, Article 10 provides for the obligation of states parties to hold meetings at least once in two years, as well as to submit regular reports on the implementation of the Convention. Article 15 states that states will form "on a consensus basis, optional arrangements of a non-confrontational, non-judicial and consultative nature for reviewing compliance with the provisions of this Convention".

Parties to the Convention established the Compliance Committee as innovative mechanism for reviewing compliance with the Convention. The Compliance Committee represents unique compliance mechanism in the field of international environmental law, since the individuals and groups are entitled to make communications concerning a Party's compliance with the provided obligations. The Committee is not judicial body issuing binding decisions about state responsibility for breach of the Convention; thus, it rather makes recommendations to the parties. The mandate of the Committee comprises not only consideration of communication on compliance; it may also prepare reports concerning the implementation of the Convention (Morgera, 2005).

The main research question in this paper is referring to the analysis of the basic postulates of public participation in environmental governance according to the provisions of the Aarhus Convention. Therefore, the special attention will be devoted to the following issues:

- the right to an adequate environment

- the right to an access to environmental information

- the right to participate in environmental decision-making process

- the right to access to justice in environmental matters. 
An innovative dimension of the Aarhus Convention is referring to its transboundary character, which would represent a special subject of research in the paper.

\section{Methodology}

The main objective of this article is to examine from the perspective of the Aarhus Convention, mechanisms for public involvement in environmental governance. Analytical methods will be used to explain the connection between the basic postulates included in the Aarhus Convention and the main principles of good governance in environmental matters. Normative methods would presents the provisions of the Aarhus Convention related to the rights of access to information, public participation, and equal access to justice, as well as to the transboundary characteristics of the Convention, as its crucial segments in the light of establishing good governance. By using the same method, special attention would be paid to transposing and implementing the requirements of the Aarhus Convention in the legal system of the Republic of Serbia. Using the case study research method, authors of the article will examine relevant practice of the Compliance Committee in order to understand the implementation of complex requirements defined by the Arhus Convention in the legislative framework of States Parties. The above-mentioned methods will provide researchers with an opportunity to analyze the data with reference to the original research questions.

\section{Right to an adequate environment in the light of environmental governance}

The Aarhus Convention creates linkages between human rights and protection of environment. The parties to the Convention have legally recognized a human need for adequate environment in the form of human right (Etinski, 2013). Therefore, the Aarhus convention represents the most ambitious effort to create international legal standards within the sphere of the environmental human right.

The Convention guarantees the right to an adequate environment in the preamble and in Article 1, stating that "every person has the right to live in an environment adequate to his or her health and well-being, and the duty, both individually and in association with others, to protect and improve the environment for the benefit of present and future generations". The above formulation differs from the standard approach contained in human rights regulations. Human rights generally imply a certain obligation of states that correspond to the rights of individuals. In order to realize this obligation, the state can impose certain obligations on individuals in the context of respecting human rights. Unlike above approach, the Aarhus Convention provides for the duty of individuals to protect and improve the environment through the enjoyment of human rights included in the Convention. Regardless to the fact that the text of the Convention contains the term "duty", it is, first of all, the right of an individual. The reasons for the use of this term can be seen from an aspect of the moral obligation of individuals in terms of their initiative regarding the protection of the rights envisaged by the Convention, in order to enable the enjoyment of the same rights for future generations, as well as to realize a higher level of environmental protection (Mladenov, 2017). 


\section{Trounsboundary character of the Aarhus Convention}

Environmental issues necessarily imply a global dimension and a transboundary nature; thus it is not possible to reduce the protection of the environmental human right to the framework of internal legal systems. For this reason, states are obliged, in fulfilling their obligations, to abandon the criteria of territorial jurisdiction and to ensure the exercise of this human right beyond the boundaries of their territory.

The parties to the Aarhus Convention have recognized the fact that their acts or omissions in the field of environmental protection may produce effects beyond national borders. Therefore, individuals may also require the protection of the rights proclaimed by this treaty before the Committee in order to consider compliance with obligations under the Aarhus Convention by contracting parties, regardless of the criteria of the territorial jurisdiction of states.

The Aarhus Convention foresees the transboundary element as a distinctive feature of the human right in question. Protection of the rights provided by the Convention, cannot be defined only as a legal relationship between a state and an individual under its territorial jurisdiction. The above thesis is confirmed by Article 3 of the Aarhus Convention stating that " the public shall have access to information, have the possibility to participate in decision-making and have access to justice in environmental matters without discrimination as to citizenship, nationality or domicile and, in the case of a legal person, without discrimination as to where it has its registered seat or an effective centre of its activities".

Therefore, concerning the violation of the right to an adequate environment, individuals would be obliged to prove that a particular activity has led to breach of the relevant environmental conditions prescribed by law, regardless of the issues referring to nationality or the place of residence (Bastmeijer and Koivurova , 2008).

\section{Access to environmental information}

The right to information on the environment represents the first "pillar" of the Aarhus Convention, provided by Articles 4 and 5 of the Aarhus Convention. The Convention envisages this right through the passive and active right to information. Active right is established by Article 4 which states the ability of the members of the public to request access to environmental information in the possession of state authorities, without having the obligation to express a legitimate interest. The article makes clear that the environmental information shall be available within one month after the request has been submitted or latest within two months if this extension is based on the volume and complexity of the information. Request for environmental information may be rejected according to the reasons provided by Article 4. As a special ground for the refusal of the information, Convention states the fact that the information in not in the possession of public authority or the possibility that disclosure of the regarded information would involve certain aspects of the confidentiality concerning international relations and public security. Parties have a duty to interpret reasons for refusal in a restrictive way and to consider whether the regarded information relates to the environmental emissions. 
Passive right to environmental information is established by Article 5 of the Convention which relates to the collection and dissemination of environmental information by public authorities. Article 5 obliges the parties to establish mandatory systems for obtaining information on proposed and existing activities that could have a significant impact on the environment. In addition, Article 5 states that parties of the Convention will require regular reports concerning the environmental impact of those entities whose activity have a significant impact on the environment. Both aforementioned obligations also apply to the private sector. Article 4, as well as Article 5 state that provided obligations are enacted within the framework of national legislation, which allows parties to the Convention significant discretion to decide which information should be withheld (Mason, 2010).

The practice of the Compliance Committee includes a significant number of cases alleging that the states parties failed to comply with Article 4. The violation of the same article was established by this body for a variety of reasons.

The Committee found that Romania breached obligation under Article 4 since this state refuse to ensure access to information contained in a study on the environmental impact assessment. Romania claimed that regarded information is part of the scientific study protected by copyright, thus its publication is only possible with the consent of the author. The Committee concluded that the failure of publication of this study, based on intellectual property rights, should not be allowed due to the fact that it is prepared for public participation in the administrative procedure (Andrusevych et al., 2011).

In the case against Spain, the Compliance Committee decided that the refusal of a public authority to provide the environmental information in the form requested by the requestor, a CD for a cost of 13 Euro instead of paper copies in the amount of 600 pages for a cost of 2.05 Euro per page represents the violation of the Article 4 of the Convention (Andrusevych and Kern, 2016). Regarding the deadline within state authorities are obliged to respond to the request, the Compliance Committee pointed out that the response must be made within a maximum of two months, regardless of the fact whether the requested information became available to the public by its publishing on the website (Zengerling, 2013).

\section{Public participation in environmental decision-making}

The right to affect decision-making is one of the most significant components of civil and political rights. This right has been emphasized by the Convention and protected through binding rules according to which parties have a duty to provide opportunities for the public to submit comments and opinions relevant to the proposed activity (Davies, 2007).

The right of the public to participate in environmental decision-making process is regulated within the framework of Articles 6, 7 and 8 of the Convention. This right is achieved through specific activities, drafting of plans, programs and policies, as well as in the field of executive regulation. Specific activities include those listed in Annex I to the Aarhus Convention, as well as all activities that may have a significant impact on the environment. The Convention requires the interested public to be informed at an early stage of the decision-making process when it can exercise effective participation. 
According to Article 6 of the Convention, States parties are obliged to notify the public concerned, inter alia, about the proposed activities, the nature of possible decisions, the envisaged procedure, the time and place of holding each public hearing, the opportunities for the public to participate. Furthermore, states should ensure that decisions taken in the proceedings manifest the results of public participation. The public has no power to veto a decision, however, the decision-making body cannot simply dismiss the comments and opinions of the public without serious consideration.

It is important here to make distinction between "public" and "concerned public" in the context of the interpretation of the conditions concerning legal standing. Article 2 of the Convention states that the category "the public" is referring to "one or more natural or legal persons, and, in accordance with national legislation or practice, their associations, organizations or groups". The "the concerned public" is defined by the same article as members of the public affected or interested in the environmental decision making.

Article 7 of the Convention regulates the participation of the public relating to plans, programs and policies in the field of environment. It is stipulated that States parties should draw up adequate measures for public participation in the process of preparing plans, programs and policies relating to environmental issues in a transparent framework.

Article 8 of the Convention prescribes public participation in the preparation of executive regulations and other generally applicable legally binding rules that may have a significant impact on the environment. In the context of the exercise of that right, parties to the Convention should take certain measures to make the draft of the rules available to the public, as well as measures to ensure the public participation in the hearing. Regardless of the fact that the Aarhus Convention does not apply to legislative bodies, Article 8 can be applied to the executive phase of drafting the rules, although they must be adopted by parliament later.

Article 6 and Article 7 have been the ground for a significant number of the decisions by the Compliance Committee. The Committee considers it important to point out that determination whether certain decision is referring to Article 6 or 7 could be difficult. However, the Committee found that it is significant "to identify what the legal effects of an act are - whether an act constitutes a decision under article 7 or a first phase/intention for a planned activity under article 6 , because only some of the public participation provisions of article 6 apply to decisions under article 7" (OHCHR - Individual Report on the Convention on Access to Information, Public Participation in Decision-Making and Access to Justice in Environmental Matters, 2013).

In the view of the Committee, Armenia did not adequately implement its obligation in Article 7 of the Convention by failing to ensure the possibility for the public to participate in a procedure determining the manner of use of a particular land through an act of the executive authority. In an application against Slovakia, the Austrian NGO claimed that Slovakia had violated the obligation under Article 6 of the Convention, based on the fact that the public authorities did not involve the public in the decision making process concerning the construction of a nuclear power plant in Mohovce. The 
Compliance Committee concluded that such a failure of Slovakia represents a breach of Article 6 (Andrusevych et al., 2011).

Public participation in decision making process is one of the crucial components of a democratic society, which gives full legitimacy to the decisions made by the authorities. However, this procedure raises numerous challenges in practice for the parties to the Convention. Motivation of the public to participate in procedures, slowing down the decision making process due to the involvement of the wider public, and increasing the overall costs of implementing the procedure, represent only some of the difficulties encountered by the countries (Mladenov, 2017).

\section{Access to justice in environmental matters}

Access to justice is one of the major components of the development of environmental governance and the law of sustainable development on domestic and international levels (Stec, 2003). Article 9 secures an access to review procedures - judicial or administrative. The right to access to justice in environmental matters is guaranteed by Article 9 of the Convention. The provisions establishing this right shall apply in cases where any of the previous two rights, which are covered by the Convention, have been violated.

The scope of Article 9 actually covers three separate rights. Article 9(1) states that the members of the public, who has requested environmental information have an access to review procedure before a court or another independent and impartial body established by law, in order to examine whether a party was complying with Article 4 of the Convention in its treatment of the request. In accordance with the Article 9(2) the concerned public should have an access to review procedures to challenge the procedural and substantive legality of any activity listed in Annex I. Article 9(3) provides the public with an "access to administrative or judicial procedures to challenge acts and omissions by private persons and public authorities which contravene provisions of its national law relating to the environment".

The first paragraph of Article 9 refers to review procedures for the protection of the right to environmental information, while the second paragraph of the same article refers to access to justice in relation to the right to participate in environmental decision-making process. The third paragraph states that parties to the Convention shall ensure to members of the public the right to review the compliance of the acts of natural persons or public authorities with the provisions of national environmental law, in the form of administrative and judicial proceedings, when they meet any conditions prescribed by domestic law. In the next paragraph of the same article, a request was made to provide adequate and effective remedies and court interim measures in the above mentioned procedures, and that decisions made pursuant to this article are in written form and made available to the public. It further states the obligation of the states parties to make information on the possibility of initiating administrative and judicial procedures for the use of remedies available to the public. 
The practice of the Compliance Committee in regard to Article 9, includes cases concerning the non-compliance by parties with the duties to provide appropriate and effective remedies, as well as the procedures that are fair, equitable, timely and not prohibitively expensive (Treves et al., 2005). In formulating the requirement that procedure should be fair, the Committee pointed out that it refers to fairness for the claimant, not the defendant (ACCC/C/2008/27, ECE/MP.PP/C.1/2010/6/Add.2).

\section{The basic postulates of the transposition of the Aarhus Convention into the legal system of the Republic of Serbia}

The Republic of Serbia ratified the Aarhus Convention in 2009 with adoption of the Law on Ratification of the Convention on Access to Information, Public Participation in Decision Making and Access to Justice in Environmental Matters. Provisions of the Convention are included in most of Serbia's existing legislation, establishing greater openness in environmental matters and contributes towards society's goals of sustainable development (Strategy for Implementing the Convention on Access to Information, Public Participation in Decision-making and Access to Justice in Environmental Matters - The Aarhus Convention, 2011).

Right to environmental information is guaranteed by the Constitution of the Republic of Serbia from 2006 in the Article 74. Law on Free Access to Information of Public Importance provides a realization of constitutionally guaranteed right to information. In this sense, the scope of information of public importance is determined, as well as a specific legal regime of the right to access information of public importance.

Law on Environmental Protection states the obligation of public authorities to inform the public about the state of the environment, as well as about warning measures or the pollution that can pose a threat to human life and health. Under Article 79, the same law regulates various issues related to the provision of environmental information at the request of natural or legal persons, while Article 80 establishes grounds for rejecting this request.

Furthermore, the Nature Conservation Law in Article 115 states the obligation of the authorities to provide access to information regarding the protection of the nature, except in cases concerning the confidentiality of the proceedings of public authorities in accordance with the national law.

Public participation in environmental decision-making is established as one of the fundamental principles in the Law on Environmental Protection. In accordance with this act, the public has a right to participate in decision making about: environmental impact assessment of projects whose realization may result in environmental pollution or threat for environment and human health; strategic assessment of plans and programs on environment, and approving new or existent installations.

In addition, public participation represents significant component of the provisions of the Law on Environmental Impact Assessment. This act guarantees the right to environmental information to the concerned public in all three phases of the 
environmental impact assessment process. The competent authority, when deciding on approval of a EIA Study, is obliged to take the opinion of public into account and notify it on the decision made, the main reasons on which the decision is based, and on the most important measures that the project manager shall undertake in order to prevent, reduce or eliminate harmful influences (Drenovak Ivanović, 2011).

Concerning the implementation of the provisions included in Article 9 of the Convention, current legislation in Serbia has two modes of legal protection in environmental matters in administrative proceedings. The first relates to the protection of rights before the competent administrative body and realized investment appeal as a regular legal remedy, while the second mode of legal protection in environmental administrative matters is related to the possibility of inspection that is initiated by filing an application to the competent administrative authority (Drenovak Ivanović, 2011).

Review procedure requirements relating to information requests provided by Article 4 of the Convention are established by Law on Environmental Protection, Law on Environmental Impact Assessment and Law on Integrated Pollution Prevention and Control. The same legal framework provides the access to justice related to the review of decisions on public participation under Article 6 (Strategy for Implementing the Convention on Access to Information, Public Participation in Decision-making and Access to Justice in Environmental Matters - The Aarhus Convention, 2011).

\section{Concluding remarks}

The significant component of the environmental protection is referring to governance and competent authorities that have a strong influence toward the realization of the environmental policies and actions, as well as in achieving outcomes in this field. The good environmental governance is needed in order to address the most urgent environmental challenges that represent the significant threat to the humanity and its survival.

One of the most important objectives of the Aarhus Convention refers to protection of the planet and its ecosystems by creating participatory democratic system. Therefore, the Convention represents the shared concern of the parties to ensure government accountability and responsiveness in the environmental field. The transposition of the requirements of the Aarhus Convention represents of a valuable contribution to the process establishing good environmental governance. By creating a linkage between human rights and environmental issues, the Convention develops public participation in environmental governance to the level of a special human right to an adequate environment that is exercised through three particular rights in environmental matters - access to information, to participation in decision-making and access to justice. The protection of the right to an adequate environment, as legal recognition of human need to live in environment that is adequate for human health and well-being, represent the ground of the Aarhus Convention to strengthen the democracy and transparency of the public authorities in the field of environmental protection. 
By establishing the Compliance Committee, as innovative compliance mechanism, members of the public have an opportunity to seek remedies at the international level concerning a compliance of the parties with the provided obligations. In the light of above fact, the citizens could determine the future success of the Convention as an important instrument that should contribute to more efficient environmental protection and realization of the principle of sustainable development.

The Republic of Serbia ratified the Aarhus Convention in 2009. Provisions of the Convention are mostly implemented into the legal system of the Republic of Serbia, establishing greater openness in environmental matters by creating the possibilities for the citizens to control public authorities and to make important contribution to the protection of environment.

Finally, in order to establish an effective legal framework in the context of the dealing with the growing environmental crisis, the protection of the rights provided by the Aarhus Convention, must be based on an empowerment to the civil society, improving public environmental awareness and the demand for public participation in decision-making processes that could affect their lives, as well as the environment and its sustainability.

\section{Conflict of interests}

The authors declare no conflict of interest.

\section{References}

1. Andrusevych, A., Alge, T., \& Konrad, C., (2011). Case Law of the Aarhus Convention Compliance Committee (2004-2011), Retrieved from https:/www. eufje.org/images/DocAarhus/Aarhus\%20CC\%20case-law.pdf ( July 25, 2018).

2. Andrusevych, A., \& Kern S., (2016). Case Law of the Aarhus Convention Compliance Committee (2004-2014), Retrieved from https:/www.unece.org/ fileadmin/DAM/env/pp/compliance/CC_Publication/ACCC_Case_Law_3rd_ edition_eng.pdf ( July 25, 2018).

3. Application against United Kingdom, ACCC/C/2008/27, ECE/ MP.PP/C.1/2010/6/Add. 2, 24 September 2010.

4. Bastmeijer, K., \& Koivurova, T., (2008). Theory and Practice of Transboundary Environmental Impact Assessment, Martinus Nijhoff Publishers, Boston.

5. Drenovak Ivanovic, M., (2011). Implementation of the Aarhus Convention in Serbia, European Energy and Environmental Law Review, 2(2), 58-71.

6. Etinski, R., (2013). Specific features of human rights guaranteed by the Aarhus Convention, Collected Papers of the Faculty of Law in Novi Sad, 47( 2), 79-92.

7. Individual Report on the Convention on Access to Information, Public Participation in Decision-Making and Access to Justice in Environmental Matters, (2013). Office Of The United Nations High Commissioner For Human Rights, Special Procedures of the United Nations Human Rights Council, U.N. Doc. A/65/38(SUPP). 
8. Law on Environmental Impact Assessment, "Official Gazette of the Republic of Serbia", no. 135/04, 36/09 and 88/10. [in Serbian: Zakon o o proceni uticaja na životnu sredinu, ,Službeni glasnik Republike Srbije“, br. 135/04, 36/2009 i 88/2010].

9. Law on Environmental Protection of the Republic of Serbia, "Official Gazette of the Republic of Serbia”, no. 135 / 04-14 / 16. [in Serbian: Zakon o zaštiti životne sredine Republike Srbije, ,Službeni glasnik Republike Srbije “, br. 135/04-14/16].

10. Law on Integrated Pollution Prevention and Control, "Official Gazette of the Republic of Serbia”, no. 135/04. [in Serbian: Zakon o o integrisanom sprečavanju i kontroli zagađivanja životne sredine, ,Službeni glasnik Republike Srbije“, br. 135/04].

11. Mason, M., (2010). Information Disclosure and Environmental Rights: The Aarhus Convention”, Global Environmental Politics, 10(3), 10-31.

12. Mladenov, M., (2017). The right to an adequate environment as a basic human right, doctoral dissertation, the Faculty of Law in Novi Sad, Novi Sad. [in Serbian: Pravo na odgovarajuću životnu sredinu kao osnovno ljudsko pravo, doktorska disertacija, Pravni fakultet u Novom Sadu, Novi Sad].

13. Morgera, E., (2005). An Update on the Aarhus Convention and its Continued Global Relevance, The Review of European, Comparative \& International Environmental Law, 14(2), 138-147.

14. Nature Conservation Law, "Official Gazette of the Republic of Serbia", no. 36/09 and 88/10. [in Serbian: Zakon o zaštiti prirode, „Službeni glasnik Republike Srbije“", br. 36/2009 i 88/2010].

15. Pallemaerts, M., (2011). The Aarhus Convention at Ten Interactions and Tensions between Conventional International Law and EU Environmental Law, Europa Law Publishing, Amsterdam.

16. Stec S., (2003). Handbook on Access to Justice under the Aarhus Convention, The Regional Environmental Center for Central and Eastern Europe, Hungary.

17. Strategy for Implementing the Convention on Access to Information, Public Participation in Decision-making and Access to Justice in Environmental Matters - The Aarhus Convention, (2011). The Ministry of Environment, Mining and Spatial Planning, Belgrade, Retrieved from https://www.osce.org/ serbia/89086?download=true (June 15, 2018).

18. Constitution of the Republic of Serbia, "Official Gazette of the Republic of Serbia”, no. 98/06. [in Serbian: Ustav Republike Srbije, „Službeni glasnik Republike Srbije“, br. 98/06].

19. Treves, T., Fodella A, \&\&Tanzi A. (2005). Civil Society, International Courts and Compliance Bodies, Cambridge University Press, US.

20. Zengerling, C., (2013). Greening International Jurisprudence: Environmental NGOs before International Courts, Tribunals, and Compliance Committees, Martinus Nijhoff Publishers, Leiden, Netherlands. 